\title{
CORRECTION
}

\section{Correction to: A Review of Techniques of Intercostal Nerve Blocks}

\author{
Yasmin Elkhashab $^{1}\left[\right.$ Dajie Wang ${ }^{1}$
}

Published online: 27 November 2021

(c) Springer Science+Business Media, LLC, part of Springer Nature 2021

Correction to: Current Pain and Headache Reports (2021) 25:67 https://doi.org/10.1007/s11916-021-00975-y

The "Methods and Results" section heading in the original publication contains added data. The original article has been corrected.

Publisher's Note Springer Nature remains neutral with regard to jurisdictional claims in published maps and institutional affiliations.

The online version of the original article can be found at https:// doi.org/10.1007/s11916-021-00975-y.

Yasmin Elkhashab

yasmin.khashab@gmail.com

1 Thomas Jefferson University Hospital, Philadelphia, PA, USA 